\title{
Allelopathic Assessment of Aqueous Extracts of Winter Weeds on Growth of Little Canary Grass (Phalaris minor Retz.) and Wheat (Triticum aestivum L.)
}

\author{
Aaradhana Chilwal*, S.P. Singh, V.P. Singh, B.S. Mahapatra, \\ D.K. Shukla and Vasundhara Kaushik
}
Department of Agronomy, Govind Ballabh Pant University of Agriculture and Technology, Pantnagar 263145, Uttarakhand, India
*Corresponding author

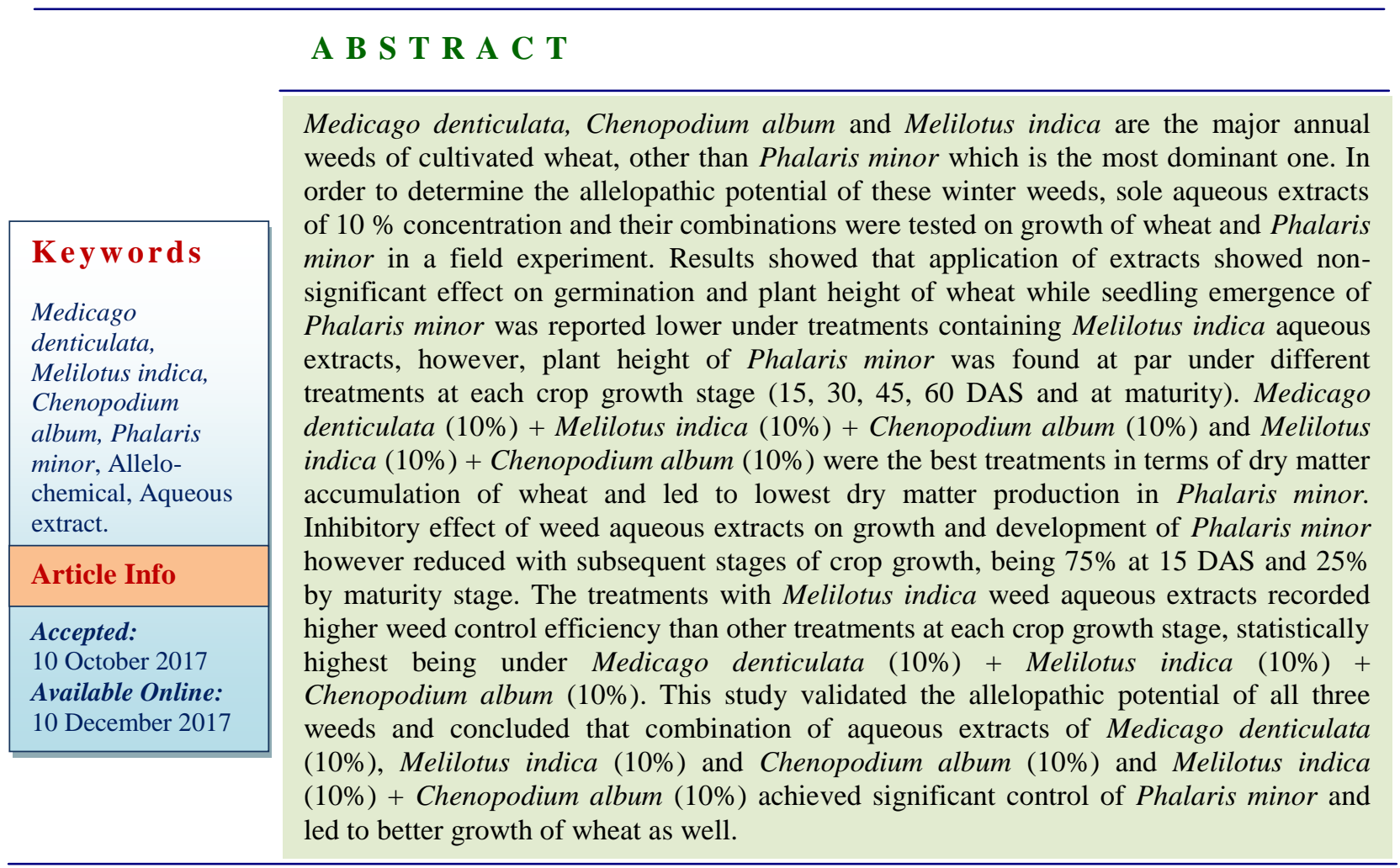

\section{Introduction}

Weed infestation is a major bottleneck to higher wheat productivity also. Wheat fields in Northern India are badly infested with wide range of grassy and non-grassy weeds in general. Little seed canary grass (Phalaris minor Retz.) has been identified as the most problematic grassy weed by virtue of its strong competitive behavior. In last few decades, Phalaris minor has emerged as a major threat to productivity and sustainability of wheat based cropping systems (Chhokar et $a l ., 2008)$ and can cause yield reductions of up to $100 \%$ (Chhokar and Malik, 2002). It requires huge amounts of herbicides for its 
control (Om et al., 2002). Isoproturon was recommended for the control of Phalaris minor in wheat. But extensive use of isoproturon over many years has led to the evolution of resistance in Phalaris minor in northwest India (Chhokar and Malik, 2002). Therefore, continued reliance on isoproturon after the development of resistance resulted in a heavy buildup of Phalaris minor populations, as competition from other weeds was removed. This caused heavy yield losses in wheat. The main reason for winter wheat cultivars varied tolerance to herbicide is because of diverse viability to plant metabolic and morphological properties that govern herbicide uptake and translocation. This led to adoption of fenoxaprop, clodinafop, and sulfosulfuron in isoproturon resistant areas since 1997 that initially gave higher yields, but resulted in a weed flora shift and resistance problems at few places, which eventually reduced yields and increased the cost of weed management. Solution to the chemical weed control related problem could be found in the development of a weed control system with the principle of greening and environmental protection simultaneously with increased weed control and saving energy (Stoimenova et al., 2008). Plants posses various naturally occurring chemicals in the form of secondary metabolites which may leach out from their various parts to the surrounding rhizosphere either as exudates or rain-residues that may directly or indirectly influence germination, growth and other developmental processes of nearby plants (Sajjad et al., 2007; Iqbal et al., 2010). In this connection, allelopathic plants may widely be used in sustainable agriculture for their potential role in herb/weed and insect/pest management. Studies specifically exploring the management of Phalaris minor by using medicinal/allelopathic plants are very few (Om et al., 2002). However, the three major broad leaved weeds of wheat- Medicago denticulata, Melilotus indica and
Chenopodium album are known to release certain allelochemicals like phenolic compounds, flavonoids, terpenoids, alkaloids, steroids, carbohydrates, and amino acids etc. from their roots, stems, leaves and decomposition products that inhibit the germination and growth of number of crop plants and weed species. This study was undertaken with the objectives of evaluating the allelopathic effect of aqueous extracts of Medicago denticulata, Melilotus indica and Chenopodium album at $10 \%$ concentration as sole and combined pre emergence application on growth of little canary grass (Phalaris minor Retz.) and wheat (Triticum aestivum L.) and to determine the weed control efficiency of these aqueous extracts.

\section{Materials and Methods}

\section{Collection of donor plant material}

The fresh biomass of required weeds was collected from the Norman E. Borlaug Crop Research Centre, Govind Ballabh Pant University of Agriculture and Technology, Pantnagar during rabi season 2015-16.

\section{Collection of test materials}

Wheat (Triticum aestivum L.) and Phalaris minor Retz. were used to test the allelopathic potential of aqueous extracts of Chenopodium album, Medicago denticulata and Melilotus indica. The seeds of wheat and Phalaris minor were collected from Norman E. Borlaug Crop Research Centre, Govind Ballabh Pant University of Agriculture and Technology, Pantnagar the seeds of Phalaris minor were of rabi season 2014-15.

\section{Preparation of aqueous extracts from weed samples}

Biomass of the weeds collected was shade dried for one week at the shade area of Weed 
Agronomy block centre in Norman E. Borlaug Crop Research Centre, Govind Ballabh Pant University of Agriculture and Technology, Pantnagar and then kept in plate dryer for 72 hours at $65 \pm 5^{\circ} \mathrm{C}$ in processing laboratory. After complete drying the entire biomass was finely grinded. Grinded biomass of weed plant was weighed using electronic balance, then was well mixed in distilled water with 1: $2(\mathrm{w} / \mathrm{v})$ ratios and soaked for 48 hours at room temperature; the mixture was then filtered using muslin cloth. Using this method weed aqueous extracts of $50 \%$ were prepared by adding $500 \mathrm{~g}$ of grinded sample to distilled water and making the final volume to 1.01 . $50 \%$ of aqueous solution was further diluted by adding water to get $10 \%$ extract for application to the field. Combination treatments were prepared by mixing the sole extracts in equal amount.

\section{Results and Discussion}

\section{Plant density}

In case of both, wheat and Phalaris minor, maximum inhibition of germination and seedling emergence was reported under Medicago denticulata $(10 \%)+$ Melilotus indica $(10 \%)+$ Chenopodium album (10\%) and Melilotus indica (10\%) + Chenopodium album (10\%). Number of shoots of Phalaris minor under Medicago denticulata $(10 \%)+$ Melilotus indica (10\%) + Chenopodium album (10\%) was 75.0\%, 49.7\%, 38.9\%, $27.7 \%$ and $26.6 \%$ less than that under control at 15 DAS, 30 DAS, 45 DAS, 60 DAS and at maturity. At 15 DAS and 30 DAS, the number of shoots of wheat per square metre did not differ significantly under different treatments but at later stages, the inhibition of seedling emergence of wheat was comparatively better under Medicago denticulata $(10 \%)+$ Melilotus indica $(10 \%)+$ Chenopodium album (10\%) and Melilotus indica $(10 \%)+$ Chenopodium album (10\%) leading to lower number of shoots per square meter. But in subsequent stages, wheat under the above mentioned treatments started performing better in terms of number of shoots per square meter due to comparatively less competition from Phalaris minor because the population of Phalaris minor was already low under these treatments due to their higher germination inhibition potential compared to other treatments. Inhibition of seedling emergence leading to low plant density was may be due to alteration in variety of physiological processes like cell division, cell differentiation, ion and water uptake, water status, phytohormone metabolism, respiration, photosynthesis and enzymatic functions in plants as was suggested by Singh et al., (2003) and Belz and Hurle (2004). Effect of treatments on density $\left(\mathrm{No} / \mathrm{m}^{2}\right)$ of Phalaris minor at various crop growth stages is given in Table 1.

\section{Plant height}

While considering the plant height of wheat crop at various crop growth stages $(15,30,45$, 60 DAS and at maturity), the different weed aqueous extracts recorded non-significant difference. Numerically, at each crop growth stage the plant height was recorded highest under control. Phalaris minor at different crop growth stage $(15,30,45,60$ DAS and at maturity) attained maximum height under control due to highest competition between wheat and Phalaris minor as weed infestation was highest in control plots. Among aqueous extracts of different weeds, the Phalaris minor height was statistically at par at every stage of observation.

\section{Dry matter accumulation}

At 30 DAS, in wheat, dry matter accumulation gave non-significant results under different treatments. But by the stage of maturity, Medicago denticulata (10\%) + 
Melilotus indica (10\%) + Chenopodium album (10\%) and Melilotus indica $(10 \%)+$ Chenopodium album (10\%) proved to be the best treatments for dry matter accumulation of wheat. At all the stages (15 DAS, 30 DAS, 45 DAS, 60 DAS and at maturity) significantly lowest dry matter accumulation of Phalaris minor was recorded under Medicago denticulata $(10 \%)+$ Melilotus indica $(10 \%)+$ Chenopodium album (10\%) at par with Melilotus indica (10\%) + Chenopodium album (10\%) The treatments containing
Melilotus indica weed aqueous extracts were recorded better than other treatments in restricting Phalaris minor growth and development and maintaining better performance of wheat by regulating crop weed competition.

Dry matter accumulation showed direct relation with number of shoots at every stage. Effect of treatments on dry matter accumulation $\left(\mathrm{g} / \mathrm{m}^{2}\right)$ of wheat at various crop growth stages is given in Table 2 .

Table.1 Effect of treatments on density $\left(\mathrm{No} / \mathrm{m}^{2}\right)$ of Phalaris minor at various crop growth stages

\begin{tabular}{|c|c|c|c|c|c|}
\hline \multirow[t]{2}{*}{ Treatments } & \multicolumn{5}{|c|}{ Density of Phalaris minor $\left(\mathrm{No} / \mathbf{m}^{2}\right)$} \\
\hline & 15DAS & 30DAS & 45DAS & 60DAS & $\begin{array}{c}\text { At } \\
\text { maturity }\end{array}$ \\
\hline Control (No Application) & $21(448)$ & $29(895)$ & $30(950)$ & $30(941)$ & $22(520)$ \\
\hline $\begin{array}{l}\text { Aqueous extract of Medicago } \\
\text { denticulata }(10 \%)\end{array}$ & $14(298)$ & $27(726)$ & $28(828)$ & $29(862)$ & $22(501)$ \\
\hline $\begin{array}{l}\text { Aqueous extract of Melilotus } \\
\text { indica }(10 \%)\end{array}$ & 17(316) & $24(581)$ & $25(645)$ & $26(682)$ & 19(394) \\
\hline $\begin{array}{l}\text { Aqueous extract of } \\
\text { Chenopodium album }(10 \%)\end{array}$ & 17(314) & $26(720)$ & $28(828)$ & $28(834)$ & $22(482)$ \\
\hline $\begin{array}{l}\text { Aqueous extract } \text { of } \\
\text { (Medicago denticulata } \\
\text { + Melilotus indica } 10 \%)\end{array}$ & $15(248)$ & $24(574)$ & $26(688)$ & $26(700)$ & 19(391) \\
\hline $\begin{array}{l}\text { Aqueous extract of } \\
\text { (Medicago denticulata } 10 \% \\
+ \text { Chenopodium album 10\%) }\end{array}$ & $17(312)$ & $26(722)$ & $28(812)$ & $29(846)$ & $22(486)$ \\
\hline $\begin{array}{l}\text { Aqueous extract of } \\
\text { (Melilotus indica } 10 \% \quad+ \\
\text { Chenopodium album } 10 \% \text { ) }\end{array}$ & $10(120)$ & $23(553)$ & $24(600)$ & $25(658)$ & 19(388) \\
\hline $\begin{array}{l}\text { Aqueous extract of } \\
\text { (Medicago denticulata } 10 \% \\
+ \text { Melilotus indica } 10 \%+ \\
\text { Chenopodium album } 10 \%)\end{array}$ & $10(112)$ & $21(450)$ & $24(580)$ & $25(680)$ & $19(381)$ \\
\hline Weed free & $\begin{array}{c}1.00(0.00 \\
)\end{array}$ & $\begin{array}{c}1.00(0.00 \\
)\end{array}$ & $\begin{array}{c}1.00(0.00 \\
)\end{array}$ & $\begin{array}{c}1.00(0.00 \\
)\end{array}$ & $1(0.00)$ \\
\hline SEm \pm & 0.9 & 1.04 & 1.5 & 1.36 & 1.36 \\
\hline $\mathrm{CD}(5 \%)$ & 2.0 & 3.0 & 4.4 & 4.11 & 4.09 \\
\hline
\end{tabular}

Original values are in parenthesis 
Table.2 Effect of treatments on dry matter accumulation $\left(\mathrm{g} / \mathrm{m}^{2}\right)$ of wheat at various crop growth stages

\begin{tabular}{|l|c|c|c|c|}
\hline \multicolumn{1}{|c|}{ Treatments } & 30DAS & 45DAS & 60DAS & At maturity \\
\hline Control (No Application) & 60.00 & 102.66 & 157.33 & 473.33 \\
\hline Aqueous extract of Medicago denticulata (10\%) & 54.66 & 96.00 & 162.66 & 517.33 \\
\hline Aqueous extract of Melilotus indica (10\%) & 52.00 & 106.66 & 173.33 & 536.00 \\
\hline Aqueous extract of Chenopodium album (10\%) & 58.66 & 98.66 & 169.33 & 526.66 \\
\hline $\begin{array}{l}\text { Aqueous extract of (Medicago denticulata 10\%+ } \\
\text { Melilotus indica 10\%) }\end{array}$ & 57.33 & 108.00 & 177.33 & 542.66 \\
\hline $\begin{array}{l}\text { Aqueous extract of (Medicago denticulata 10\% + } \\
\text { Chenopodium album 10\%) }\end{array}$ & 54.66 & 89.33 & 166.66 & 497.33 \\
\hline $\begin{array}{l}\text { Aqueous extract of (Melilotus indica 10\% + } \\
\text { Chenopodium album 10\%) }\end{array}$ & 50.66 & 100.00 & 194.66 & 568.00 \\
\hline $\begin{array}{l}\text { Aqueous extract of (Medicago denticulata 10\% + } \\
\text { Melilotus indica 10\% + Chenopodium album 10\%) }\end{array}$ & 49.33 & 105.33 & 193.33 & 582.66 \\
\hline Weed free & 62.66 & 117.33 & 202.66 & 592.00 \\
\hline SEm \pm & NS & 12.39 & 18.68 & 68.89 \\
\hline CD (5\%) & & & 6.18 & 22.78 \\
\hline
\end{tabular}

*NS- non significant

Table.3 Effect of treatments on weed control efficiency at various crop growth stages

\begin{tabular}{|c|c|c|c|c|}
\hline \multirow[t]{2}{*}{ Treatments } & \multicolumn{4}{|c|}{ Weed control efficiency $(\%)$} \\
\hline & 30DAS & 45DAS & 60DAS & $\begin{array}{c}\text { At } \\
\text { maturity }\end{array}$ \\
\hline Control (No Application) & 0.00 & 0.00 & 0.00 & 0.00 \\
\hline Aqueous extract of Medicago denticulata (10\%) & 4.77 & 8.07 & 4.11 & 6.80 \\
\hline Aqueous extract of Melilotus indica $(10 \%)$ & 40.87 & 32.61 & 19.64 & 17.51 \\
\hline Aqueous extract of Chenopodium album (10\%) & 6.34 & 11.94 & 7.47 & 7.35 \\
\hline $\begin{array}{l}\text { Aqueous extract of (Medicago denticulata } 10 \%+\text { Melilotus } \\
\text { indica } 10 \% \text { ) }\end{array}$ & 44.04 & 14.13 & 17.80 & 22.00 \\
\hline $\begin{array}{l}\begin{array}{l}\text { Aqueous extract of (Medicago denticulata } \\
\text { Chenopodium album } 10 \%)\end{array} \\
\end{array}$ & 5.06 & 12.77 & 4.74 & 11.53 \\
\hline $\begin{array}{l}\text { Aqueous extract of (Melilotus indica } 10 \%+\text { Chenopodium } \\
\text { album } 10 \% \text { ) }\end{array}$ & 42.87 & 33.13 & 29.75 & 24.93 \\
\hline $\begin{array}{l}\text { Aqueous extract of (Medicago denticulata } 10 \%+\text { Melilotus } \\
\text { indica } 10 \%+\text { Chenopodium album } 10 \%)\end{array}$ & 54.60 & 36.20 & 31.69 & 27.01 \\
\hline Weed free & 100.00 & 100.00 & 100.00 & 100.00 \\
\hline $\mathrm{SEm} \pm$ & 2.97 & 1.91 & 1.66 & 1.96 \\
\hline $\mathrm{CD}(5 \%)$ & 8.99 & 5.79 & 5.03 & 5.95 \\
\hline
\end{tabular}

Weed control efficiency

Medicago denticulata $(10 \%)+$ Melilotus indica $(10 \%)+$ Chenopodium album $(10 \%)$ showed statistically highest weed control efficiency at every crop growth stage being $54.60 \%, 36.20 \%$, $31.69 \%$ and $27.01 \%$ at 30 DAS, 45 DAS, 60 DAS and at maturity, which shows that it is most efficient in controlling weeds throughout the crop growth period. However, with 
subsequent growth stages, continuous decrease in weed control efficiency under Medicago denticulata $(10 \%)+$ Melilotus indica $(10 \%)+$ Chenopodium album (10\%) was recorded which showed the higher potential of weed control by the treatment during initial period than subsequent growth stages which reduces with aging of crop. Weed control efficiency under different treatments at various crop growth stages (30, 4560 DAS and at maturity) is presented in Table 3.

From the present study, it may be concluded that combination of aqueous extracts of Medicago denticulata (10\%), Melilotus indica (10\%) and Chenopodium album (10\%) and Melilotus indica (10\%) + Chenopodium album (10\%) achieved significant growth control of Phalaris minor and led to better growth of wheat as well. However, the growth inhibition of Phalaris minor decreased with subsequent stages of the crop being $75 \%$ at 15 DAS and reducing to $25 \%$ by maturity. This validated the allelopathic potential of all three weed aqueous extracts in controlling Phalaris minor.

However, allelopathic potential of aqueous extracts of Melilotus indica was recorded higher than Medicago denticulata and Chenopodium album. Thus, aqueous extract of Melilotus indica could be a useful plant product for the possible utilization as a bioherbicide under Integrated Weed Management Programmes (IWMPs) in future.

\section{Acknowledgement}

Support from Dr. S.P. Singh, JRO, Department of Agronomy, College of Agriculture, GBPUAT, Pantnagar and Dr. V.P. Singh. Professor, Department of Agronomy, College of Agriculture, GBPUAT, Pantnagar is gratefully acknowledged.

\section{References}

Belz, R.G. and Hurle, K. 2004. A novel laboratory screening bioassay for crop seedling allelopathy. J. Che. Ecol. 3:175198.

Chhokar, R.S. and Malik, R.K. 2002. Isoproturon resistant Phalaris minor and its response to alternate herbicides. Weed Technol. 16:116-123.

Chhokar, R.S., Singh, S. and Sharma, R.K. 2008. Herbicides for control of isoproturon resistant little seed canary grass (Phalaris minor) in wheat. Crop Protect., 27:719726.

Iqbal, J., Karim, F. and Hussain, S. 2010. Response of the wheat crop (Triticum aestivum L.) and its weeds to allelopathic crop water extracts in combination with reduced herbicides rates. Pak. J. Agricult. Sci. 47:309-316.

Om, H., Dhiman, S.D., Kumar, S. and Kumar, H., 2002. Allelopathic response of Phalaris minor to crop and weed plants in rice-wheat system. Crop Protect., 21: 699705 .

Sajjad, H., Sadar, S., Khalid, S., Jamal, A., Qayyum, A. and Ahmad, Z. 2007. Allelopathic potential of Senna (Cassia angustifolia Vahl.) on germination and seedling characters of some major cereal crops and their associated grassy weeds. Pakistan J. Agricult. Sci., 39(4): 11451153.

Singh, H.P., Batish, D.R. and Kohli, R.K. 2003. Allelopathic interactions and allelochemicals: New possibilities for sustainable weed management. Crit. Rev. Plant Sci. 22: 239-311.

Stoimenova, I., Mikova, A. and Aleksieva, S. 2008. Role of allelopathy in weed management of crop production. $J$. Agricult. Sci. 41(3):3-13.

\section{How to cite this article:}

Aaradhana Chilwal, S.P. Singh, V.P. Singh, B.S. Mahapatra, D.K. Shukla and Vasundhara Kaushik. 2017. Allelopathic Assessment of Aqueous Extracts of Winter Weeds on Growth of Little Canary Grass (Phalaris minor Retz.) and Wheat (Triticum aestivum L.). Int.J.Curr.Microbiol.App.Sci. 6(12): 984-989. doi: https://doi.org/10.20546/ijcmas.2017.612.109 